\title{
Atenção Centrada no Usuário como Atributo do Trabalho em Equipe e Prática Interprofissional Colaborativa na Atenção Básica
}

\author{
Agreli, Heloise Lima Fernandes; Peduzzi, Marina; Loqueti, Crislaine; Silva, Mariana \\ Charantola \\ EEUSP — heloiselima@hotmail.com
}

Introdução: As mudanças que ocorrem na concepção de saúde doença, no perfil populacional e de morbimortalidade e crescente complexidade da rede de serviços, apontam para a necessidade de mudança na gestão: da prática profissional isolada de cada área, para o trabalho em equipe e prática interprofissional colaborativa. Nesse contexto se destaca a atenção centrada no usuário como atributo que pode contribuir para efetivar a transição assinalada e para o fortalecimento da humanização da atenção à saúde. Objetivos: Analisar a atenção centrada no usuário como atributo para o trabalho em equipe e prática interprofissional colaborativa. Métodos: Realizou-se revisão de literatura nas bases de dados Medline, Scopus, CINAHL, Lilacs e Scielo com os descritores específicos de cada base e o critério de inclusão: artigos que tratassem da prática colaborativa, trabalho em equipe e assistência centrada no paciente como assuntos principais, no contexto da Atenção Primária à Saúde. como critério de exclusão: estudos que abordassem as temáticas de forma isolada, por exemplo, fazendo referência apenas a assistência centrada no paciente ou somente à prática colaborativa das equipes. Resultados: nas bases de dados nacionais não foi identificado nenhum registro com os critérios referidos. nas bases de dados internacionais observou-se que as discussões versam sobre aspectos organizacionais, educacionais e competências para a prática colaborativa centrada no paciente. Observou-se ausência de consenso sobre os termos patient centered care e collaborative practice. o termo colaboração demonstrou-se comumente definido através de 5 conceitos: compartilhamento, parceria, poder, interdependência e processo. Os autores colocam a questão da participação do paciente nas equipes colaborativas, porém a forma dessa participação variou, demonstrando ser mais centrada no paciente ou centrada nas recomendações da equipe. As lacunas identificadas referem-se a escassez de estudos que incluam a perspectiva dos pacientes nos estudos sobre a prática colaborativa centrada no paciente. Assim como se verificou a ausência de estudos que sugiram formas para integração dos pacientes na equipe de saúde, como membro importante na tomada de decisões. a própria literatura encontrada sugere como assunto de pesquisa a compreensão do lugar que o paciente gostaria de ter na colaboração interprofissional. Conclusões: Observa-se escassez na literatura nacional de produções que relacionem a atenção centrada no usuário e a prática interprofissional colaborativa. a literatura internacional não apresenta consenso sobre os termos, mas há concordância, sobretudo na literatura canadense e americana acerca da atenção centrada no usuário como atributo para prática interprofissional colaborativa. São necessários estudos na temática para subsidiar práticas interprofissionais colaborativas que permitam a atenção humanizada e usuário centrada.

Agreli, Heloise Lima Fernandes; Peduzzi, Marina; Loqueti, Crislaine; Silva, Mariana Charantola. Atenção Centrada no Usuário como Atributo do Trabalho em Equipe e Prática Interprofissional Colaborativa na Atenção Básica. In: Anais do Congresso Internacional de Humanidades \& Humanização em Saúde [= Blucher Medical Proceedings, num.2, vol.1]. São Paulo: Editora Blucher, 2014. ISSN 2357-7282

DOI 10.5151/medpro-cihhs-10646 